\title{
Role of Defective Apoptosis in Type 1 Diabetes and Other Autoimmune Diseases
}

\author{
Takuma Hayashi and Denise L. Faustman \\ Immunobiology Laboratory, Massachusetts General Hospital, and Harvard Medical School, \\ Charlestown, Massachusetts 02129
}

\begin{abstract}
Lymphocyte development, selection, and education are strictly controlled to prevent autoimmunity, with potentially autoreactive cells being removed by apoptosis. Dysregulation of apoptosis is a central defect in diverse murine autoimmune diseases. In murine models of autoimmune lupus, for example, mutations in the death receptor Fas (CD95) or in its ligand, FasL (CD95L), have been identified and shown to render lymphoid cells resistant to apoptosis. In contrast, select lymphoid subpopulations of mice with autoimmune diabetes manifest an increased susceptibility to apoptosis as a result of impaired activation of the transcription factor nuclear factor-kappa B (NF- $\kappa \mathrm{B})$, which normally protects cells against tumor necrosis factor-alpha (TNF- $\alpha$ )-induced apoptosis. The genetic basis of this defect in NF- $\kappa \mathrm{B}$ activation is a mutation in the promoter-enhancer region of a gene that encodes an essential subunit (LMP2) of the proteasome. Although no specific genetic defects have been identified in most common forms of human autoimmune disease, functional assays consistently demonstrate heightened apoptosis attributable to multiple death signaling pathways.
\end{abstract}

\section{Introduction}

Autoimmunity encompasses a diverse group of diseases that are defined clinically by the target organ or tissue destroyed. Rheumatoid arthritis and type 1 diabetes mellitus (also known as insulin-dependent or juvenile-onset diabetes), for example, result from a presumed T-cell attack on the joints and insulinsecreting beta $(\beta)$ cells of the pancreas, respectively. Although the clinical manifestations of each autoimmune disease are distinct, the underlying genetics of these conditions are similar, with most showing an association with the human leukocyte antigen (HLA; also known as the human major histocompatibility complex, or MHC) region of the genome or with nearby non-HLA loci (Becker et al., 1998).

Apoptosis may play a role in two different aspects of autoimmune disease. First, controlled apoptotic cell death contributes to normal T-cell selection and education. Thus, interruption of this process might result in the generation of 
autoreactive cells. Second, apoptosis might represent a lymphocyte-independent mechanism of organ or tissue destruction. To date, most experimental data as well as identified genetic defects that promote or impair apoptosis have implicated abnormal T-cell selection and development in autoimmunity. Although a target cell apoptotic defect, possibly involving the Fas death receptor, has been proposed to affect the pancreatic islets of individuals with type 1 diabetes (Chervonsky et al., 1997; Itoh et al., 1997; Amrani et al., 1999; Suarez-Pinzon et al., 1999), other studies have suggested that apoptosis is not a major mechanism of $\beta$-cell destruction (Kang et al., 1997,1998; Kim et al., 1999; Pakala et al., 1999; Thomas et al., 1999; Kim et al., 2000; Restifo, 2000). This chapter will focus on the role of apoptotic defects that affect education of the lymphoid system in autoimmunity.

A prominent feature of autoimmunity is the failure of autoreactive cells, either during development or subsequently, to undergo negative selection and die. Such apoptotic defects in humans and mice result in autoreactivity and may lead to marked lymphoproliferation. In certain instances, these defects have been attributed to mutations in the genes for proteins that function in apoptotic signaling pathways. One such example is the $l p r / l p r$ mouse, a model of human systemic lupus erythematosus (SLE), in which defective apoptosis results in lymphoproliferation and generalized autoimmunity. These animals harbor a spontaneous mutation in the gene for Fas (Watanabe-Fukunaga et al., 1992; Watson et al., 1992; Mountz et al., 1996), a cell-surface molecule also known as CD95 that belongs to the tumor necrosis factor receptor (TNF-R) superfamily. Similarly, the gld/gld mouse, which also manifests a lupus-like autoimmune disease, harbors a point mutation in the intracellular domain of the Fas ligand (FasL) (Allen et al., 1990; Lynch et al., 1994; Ramsdell et al., 1994; Takahashi et al., 1994). The identification of these autoimmunity-associated defects in the Fas signaling pathway stimulated a search for similar mutations in humans with lupus. However, only individuals with a rare form of lupus associated with diffuse lymphoproliferation have been shown to possess a mutation in the FasL gene (Wu et al., 1996a). Only patients with the rare Canale-Smith syndrome or autoimmune lymphoproliferative syndrome have been found to harbor a Fas mutation (Rieux-Laucat et al., 1995; Drappa et al., 1996). Not unexpectedly, the lymphoproliferation apparent in these patients resembles that in $l p r / l p r$ and gld/gld mice and is thought to result from the failure of select lymphocyte populations to undergo apoptosis. Most individuals with lupus do not appear to harbor mutations in the Fas or FasL genes. Indeed, lymphocytes from such individuals manifest an increased susceptibility to apoptosis in vitro as well as increased FasL expression (Emlen et al., 1994; Mysler et al., 1994; Desai-Mehta et al., 1996; Koshy et al., 1996; Wu et al., 1996a; Kovacs et al., 1997; Lorenz et al., 1997; Wong et al., 1999). 
In most spontaneous forms of human or murine autoimmunity, severe lymphoproliferation is not a prominent feature of the disease. Indeed, we have shown that the pathogenic cells may manifest an increased susceptibility to apoptosis. In the nonobese diabetic (NOD) mouse, for example, a spontaneous model of human type 1 diabetes, lymphocytes are more susceptible to TNF- $\alpha$ induced apoptosis than are lymphocytes from control animals. This results from a defect in the activation of nuclear factor-kappa B $(\mathrm{NF}-\kappa \mathrm{B})$ (Hayashi and Faustman, 1999), a transcription factor that protects against TNF- $\alpha$-induced cell death. In addition to the accelerated apoptosis, there is increased FasL expression exhibited by peripheral blood lymphocytes from humans with lupus in vitro (Wong et al., 1999). The genetic basis of these human defects remains unknown.

Members of the TNF-R superfamily appear to play an important role in autoimmune disease. These proteins comprise an extracellular domain consisting of cysteine-rich motifs, a transmembrane domain, and a cytoplasmic tail (Liang and Fesik, 1997; Wallach et al., 1999).

Activation of NF- $\kappa \mathrm{B}$ protects cells against TNF- $\alpha$-induced apoptosis but this transcription factor also contributes to cell death mediated by Fas (Quaaz et al., 1999 ), another TNF-R family member. In addition, NF- $\kappa \mathrm{B}$ activation in response to TNF- $\alpha$ may contribute to FasL expression (Hsu et al., 1999). The interplay between these various overlapping apoptotic pathways may explain why the apoptotic defects associated with autoimmune disease confer phenotypes of enhanced or diminished T-cell selection.

\section{Genetic Risk Factors for Type 1 Diabetes Located in the MHC Region of the Genome}

Genetic risk factors for type 1 diabetes map to the MHC region of the genome. In both human type 1 diabetes and two rodent models of this disease (the NOD mouse and BB rat), pancreatic $\beta$ cells are selectively destroyed as a result of a chronic autoimmune reaction (Figure 1A and B) (Crisa et al., 1992; Rabinovitch and Skyler, 1998). The MHC region of the genome contains immune response genes that are important for T-cell education and for antigen presentation by both MHC class I and class II molecules. Studies of both humans and rodents have suggested that the centrally located MHC class II genes confer the greatest statistical risk for autoimmune disease. However, functional derangement of MHC class II genes has not been demonstrated in humans with autoimmune disease. In contrast, cellular abnormalities in expression of maturation markers or in antigen presentation have been detected in both NOD mice and diabetic humans. These defects include reduced expression of the maturation antigen CD45 and a reduced abundance of conformationally correct complexes of MHC class I molecules and self-peptides on the cell surface (Faustman et al., 1989,1991; Smerdon et al., 1993; Jansen et al., 1995). 

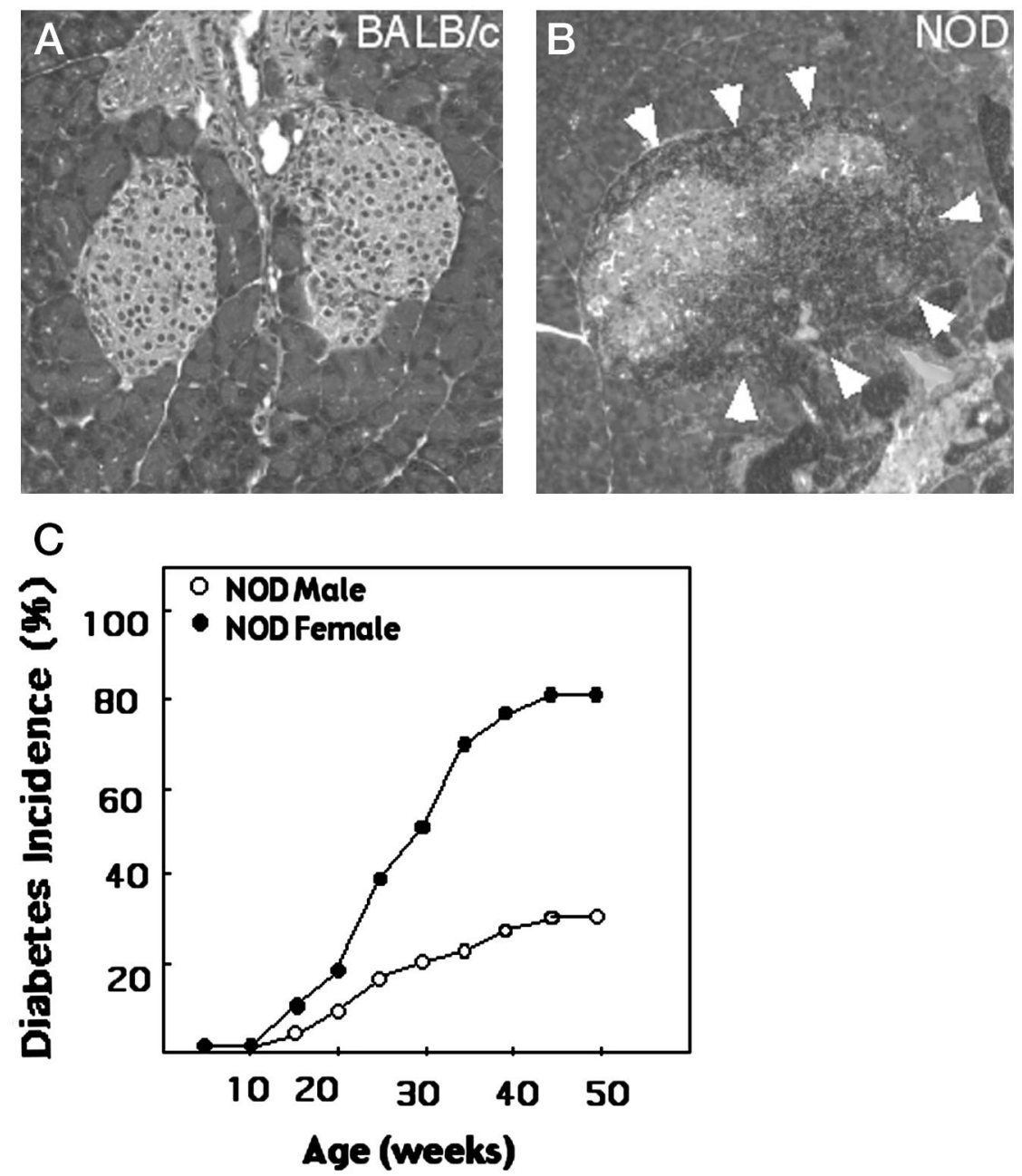

FIG. 1. Insulitis and diabetes prevalence in the NOD mouse. Sections of a normal pancreas from a 4-month-old BALB/c female mouse (A) and of a pancreas with marked leukocyte infiltration (insulitis) from a 4-month-old NOD female mouse (B). Sections were stained with hematoxylin and eosin (H\&E). Arrowheads indicate sites of extensive leukocyte infiltration. (C) Age dependence of diabetes prevalence in male and female NOD mice.

Evidence based on functional assays suggests that human autoimmune diseases are associated with impairment of antigen processing controlled by the MHC. Thus, cytosolic extracts of lymphocytes from either humans with type 1 
diabetes or NOD mice exhibit altered patterns of cleavage of test substrates by the proteasome. This results in the generation of peptides that are poorly suited for assembly with MHC class I molecules (Faustman et al., 1989,1991; Smerdon et al., 1993; Jansen et al., 1995). In addition, lymphocytes of individuals with diverse autoimmune diseases - including type 1 diabetes, multiple sclerosis, and rheumatoid arthritis - manifest a reduced expression of peptide-loaded MHC class I molecules on their surface (Faustman et al., 1991; Fu et al., 1993; Li et al., 1995). Moreover, clinical studies have shown that the antigen presentation defect correlates with disease expression in identical twins with type 1 diabetes (Faustman et al., 1991). The genes responsible for antigen processing map to the MHC region of the genome, suggesting that abnormalities in this region might underlie these various conditions.

Candidate genes in the MHC region of the genome in humans and rodents that might be responsible for the antigen presentation defects associated with autoimmune disease include those for the TAP peptide transporters and the LMP proteasome subunits. Thus, for example, both LMP2 and LMP7 are encoded by genes located in the MHC region of the genome (Figure 2). These proteins are expressed constitutively in most cell types but their expression is markedly increased in antigen-presenting cells (APCs) or lymphoid cells in response to exposure to interferon-gamma $(\gamma)$ (Fruh et al., 1992; Van Kaer et al., 1994; Hisamatsu et al., 1996; Griffin et al., 1998). Knockout (KO) mice that lack specific TAP or LMP genes exhibit abnormal T-cell selection and autoreactivity against transplants of syngeneic normal tissue (Aldrich et al., 1994; Glas et al., 1994; Van Kaer et al., 1994; Wakatsuki et al., 1994).

Ubiquitin-dependent proteolysis mediated by the proteasome, a multisubunit adenosine triphosphate (ATP)-dependent protease, plays important roles in various cellular processes, including cell-cycle progression, gene transcription, and signal transduction (Goldberg, 1995; Coux et al., 1996). In many instances, the target protein is marked for degradation or processing by both phosphorylation and ubiquitination. Cleavage of endogenous proteins by the proteasome also generates small peptide fragments that contribute to T-cell education as a result of their presentation by MHC class I molecules. Although, in general, the proteasome exhibits minimal variability in substrate selectivity and subunit composition, incorporation of the LMP2 and LMP7 subunits during assembly of the proteasome changes its specificity for self-proteins in such a manner that the suitability of the generated peptides for presentation in the peptide-binding groove of MHC class I molecules is increased (Belich et al., 1994; Gaczynska et al., 1996). The abundance of LMP2 mRNA in lymphocytes derived from NOD mice is reduced, compared with that in lymphocytes from control animals (Figure 2) (Yan et al., 1997), which likely explains, at least in part, the altered T-cell education toward self apparent in these mice. 


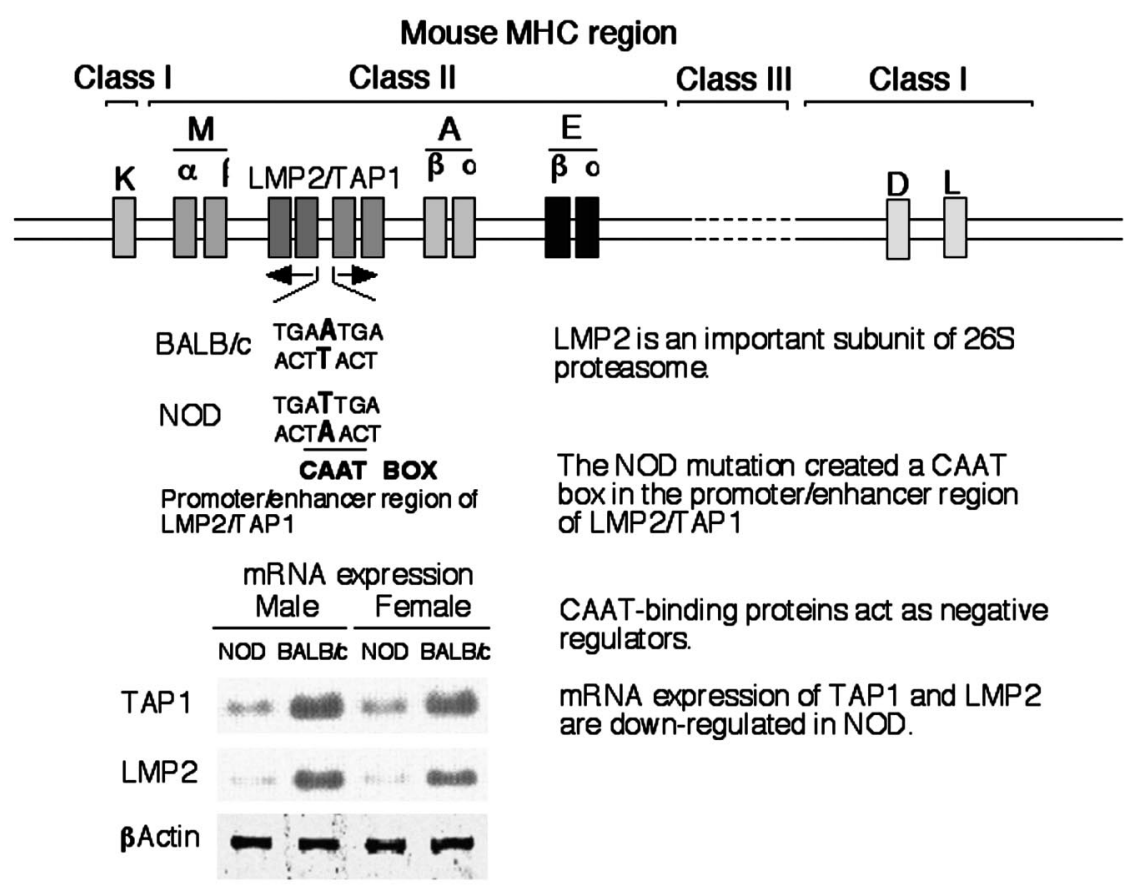

FIG. 2. Identification of a point mutation in the shared promotor-enhancer region of the LMP2 and TAP1 genes in the NOD mouse. The mutation creates a CAAT box in the shared promoterenhancer region. CAAT box-binding proteins likely act as negative regulators of gene transcription. Northern blot analysis reveals that the abundance of both LMP2 and TAP1 mRNAs is reduced markedly in splenocytes derived from adult NOD female and male mice with type 1 diabetes, compared with those in splenocytes from control BALB/c mice.

\section{The NOD Mouse: A Spontaneous Model of Type 1 Diabetes}

Type 1 diabetes usually is caused by T-cell-mediated autoimmunity, with a prediabetic state characterized by the production of autoantibodies specific for proteins expressed by pancreatic $\beta$ cells, including insulin. In general, the autoantibodies recognize intracellular proteins and likely are generated in response to islet death. The NOD mouse frequently is studied as a rodent model of human type 1 diabetes. The etiology of diabetes in the NOD mouse is complex and multifactorial (Delovitch and Singh, 1997; Rabinovitch, 1998; Atkinson and Leiter, 1999). Both $\mathrm{CD} 4^{+}$and $\mathrm{CD} 8^{+} \mathrm{T}$ cells mediate the autoimmune response, with underlying functional defects being present in bone marrow-derived APCs. Many $\mathrm{CD}^{+}$and $\mathrm{CD}^{+}{ }^{+}$-cell lines and clones with diabetogenic potential that are targeted to a variety of identified and unidentified antigens have been established from both the islets and spleen of NOD mice. Destruction of 
pancreatic $\beta$ cells appears to be mediated by both necrotic and apoptotic death triggered by invasion of islets by leukocytes, a process referred to as insulitis (Rabinovitch, 1998). Although insulitis is not apparent in NOD mice up to 3 weeks of age, its prevalence increases in both female and male animals after 5 weeks of age. A clear sex difference is observed with respect to the onset of diabetes, however (Figure 1C). In NOD females, the onset of diabetes occurs as early as 10 weeks, with the number of affected animals increasing with age (Makino et al., 1980). The cumulative prevalence of diabetes in NOD females by 50 weeks of age is $\approx 70-80 \%$. In contrast, only about $20 \%$ of NOD males are affected by diabetes at this age. The large numbers of leukocytes apparent in the islet infiltrates of NOD mice are suggestive of lymph node formation around islets (Figure 1A and B). A strain-specific characteristic of NOD mice is the accumulation of many $\mathrm{T}$ lymphocytes in peripheral lymphoid organs, the pancreas, and submandibular salivary glands. This T-cell accumulation may reflect low interleukin (IL)-2 concentrations and the resistance of thymocytes and peripheral $\mathrm{T}$ cells to the induction of apoptosis. Such apoptotic resistance may be an early phenotype of lymphoid lineages prior to disease initiation (LamhamediCherradi et al., 1998).

Type 1 diabetes in the NOD mouse, like that in humans, exhibits a marked genetic component that maps to the MHC region of the genome. We have identified a specific proteasome defect in NOD mouse lymphocytes that results from downregulation of expression of the LMP2 proteasome subunit (Figures 2 and 3) (Hayashi and Faustman, 1999), which is encoded by a gene located in the MHC genomic region. This defect both prevents the proteolytic processing required for the production and activation of NF- $\kappa \mathrm{B}$, which plays an important role in immune and inflammatory responses, and increases the susceptibility of the affected cells to apoptosis induced by TNF- $\alpha$ (Figure 4). The proteasome dysfunction in NOD mice is both tissue and developmental stage specific; it is not apparent in islet cells.

\section{Defects in Proteasome-mediated NF- $\kappa$ B Activation and T-cell Education in NOD Mice}

The proteasome mediates the processing and activation of the transcription factor NF- $\kappa \mathrm{B}$ (Figure 5). NF- $\kappa \mathrm{B}$ is activated in response to various extracellular stimuli, including IL-1, lipopolysaccharide, and TNF- $\alpha$ (Thanos and Maniatis, 1995; Verma et al., 1995; Baeuerle and Baltimore, 1996; Baldwin, 1996). It contributes to regulation of the gene expression for cytokine production, cell adhesion, lymphocyte maturation, and protection from TNF- $\alpha$-induced apoptosis, as well as antigen processing and presentation by MHC class I molecules (Bohnline et al., 1988; Cross et al., 1989; Tan et al., 1992; Beg and Baltimore, 1996; Van Antwerp et al., 1996). Insights into the various biological functions of 
A

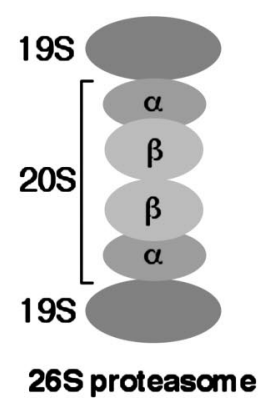

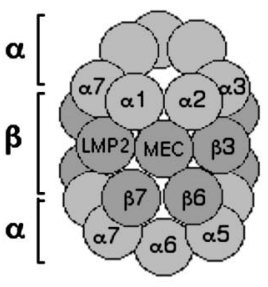

205 proteasome
B

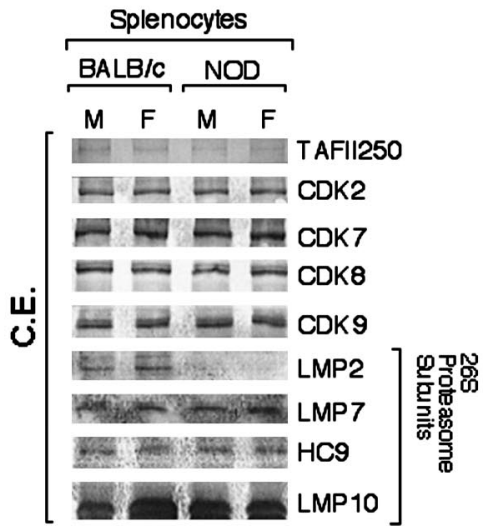

FIG. 3. Schematic representation of the central role of the proteasome in NF- $\kappa \mathrm{B}$ activation and antigen presentation in an antigen-presenting cell (APC). Proteasomes containing the LMP2 subunit generate self-peptides for presentation on the cell surface by MHC class I molecules, a process that is required for T-cell education by self-antigens. Such LMP2-containing proteasomes also are required for processing NF- $\kappa \mathrm{B}$ subunit precursors and degradation of $\mathrm{I} \kappa \mathrm{B} \alpha$, which underlies $\mathrm{NF}-\kappa \mathrm{B}$ activation. The activation of $\mathrm{NF}-\kappa \mathrm{B}$ is essential for lymphocyte maturation, protection against apoptosis, and cytokine balance. Lymphoid cells of adult NOD mice fail to produce LMP2 and are thus defective in antigen presentation and susceptible to apoptosis.

$\mathrm{NF}-\kappa \mathrm{B}$ have been provided by the generation and characterization of $\mathrm{KO}$ mice lacking either subunits of this protein or associated regulatory factors (Burkly et al., 1995; Kontgen et al., 1995; Weih et al., 1995; Franzoso et al., 1997; Bushdid et al., 1998; Caamano et al., 1998; Kanegae et al., 1998; Hu et al., 1999; Li et al., 1999a,b; Takeda et al., 1999).

Active NF- $\kappa \mathrm{B}$ exists predominantly as a heterodimer composed of p65 (RelA) and either p50 or p52 subunits. The p50 and p52 subunits are generated constitutively but their abundance is increased markedly by various extracellular stimuli, including IL-1 and TNF- $\alpha$. These proteins are generated as a result of the proteasome-mediated removal of the carboxyl termini of p105 and p100 precursors, respectively (Fan and Maniatis, 1991; Schmid et al., 1991; Palombella et al., 1994; Coux and Goldberg, 1998; Lin et al., 1998; Sears et al., 1998). In resting cells, NF- $\kappa \mathrm{B}$ is sequestered in the cytoplasm as a result of its association with $\mathrm{I} \kappa \mathrm{B} \alpha$ or other members of the $\mathrm{I} \kappa \mathrm{B}$ family of inhibitory proteins (Ghosh and Baltimore, 1990; Hayashi et al., 1993a,b). Cell stimulation results in the phosphorylation of $\mathrm{I} \kappa \mathrm{B} \alpha$ by the I $\kappa \mathrm{B}$ kinase (IKK) complex and its degradation by the ubiquitin-proteasome pathway, thereby allowing the p50-p65 or p52-p65 heterodimer to translocate to the nucleus and initiate transcription of target genes (Figure 3) (Ghosh and Baltimore 1990; Oeri et al., 1991; Palombella et al., 1994; 


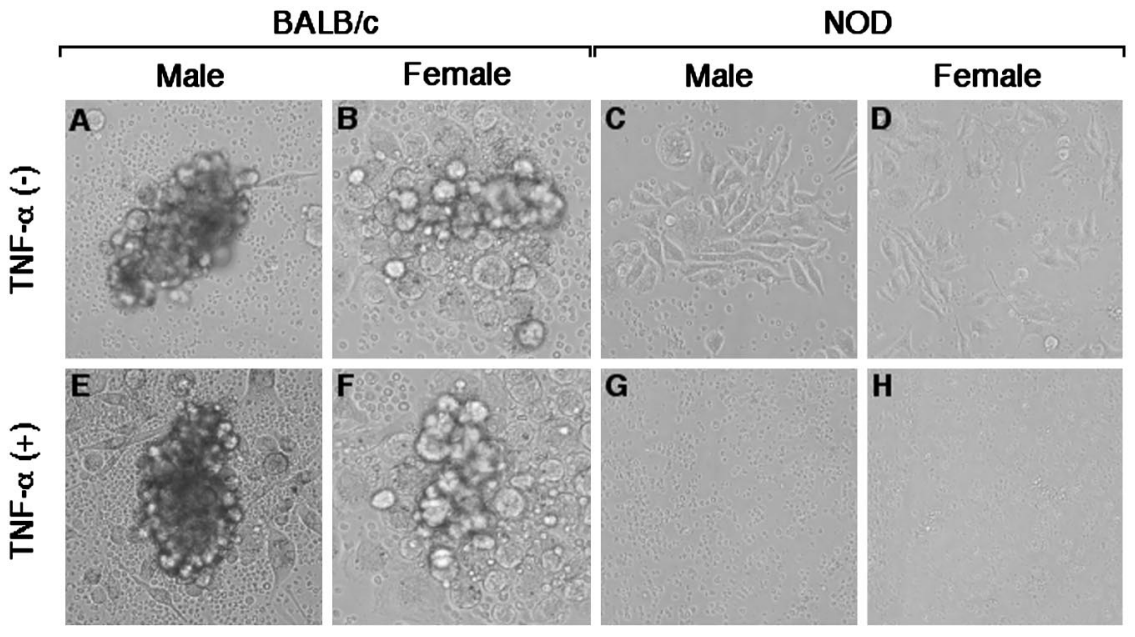

FIG. 4. Impaired granulocyte-macrophage (GM) colony formation and increased sensitivity to $\mathrm{TNF} \alpha$-induced apoptosis in NOD mouse spleen cells. Spleen cells derived from 6-week-old male or female BALB/c or NOD mice were mixed with $1.3 \%$ methylcellulose dissolved in culture medium and layered onto a bed of $0.53 \%$ agarose in culture medium. Cells were cultured for 3 weeks in the presence of GM-colony stimulating factor (CSF) $(20 \mathrm{ng} / \mathrm{ml})$ and in the absence or presence of TNF- $\alpha$ (20 ng/ml), as indicated. [Reprinted with permission from Hayashi T, Faustman D 1999 NOD mice are defective in proteasome production and activation of NF- $\kappa$ B. Mol Cell Biol 19:8646-8659. Copyright American Society for Microbiology.]

MacKichan et al., 1996; Belich et al., 1999). Complexes of p65 and p105 also have been detected but these do not appear to translocate rapidly to the nucleus in response to cell stimulation (Sun et al., 1994; Lin et al., 1998).

Our laboratory has sought to understand why, in type 1 diabetes, $\mathrm{T}$ cells treat pancreatic $\beta$ cells as foreign. We therefore have attempted to understand the process of T-cell education to self-antigens and how this process is altered in individuals with type 1 diabetes. T-cell education requires the presentation of self-antigens, a task that is undertaken by "professional" APCs such as macrophages, dendritic cells, and B cells. Until recently, it was thought that autoimmunity results from the inappropriate activation of $\mathrm{T}$ cells by foreign antigens (e.g., viral proteins) that generate cross-reactivity with self-antigens, which was considered an MHC class II defect. However, we proposed, and presented evidence for the notion, in both NOD mice and humans with type 1 diabetes, that interruption of the presentation of self-antigens by MHC class I molecules underlies the development of autoimmune disease (Faustman et al., 1991). This proposal was based on the contention that such MHC class I-mediated presentation of self-peptides is essential for the development of normal tolerance. Previously, MHC class I proteins were thought to function primarily in the 


\section{T-cell Education to Self Peptides}

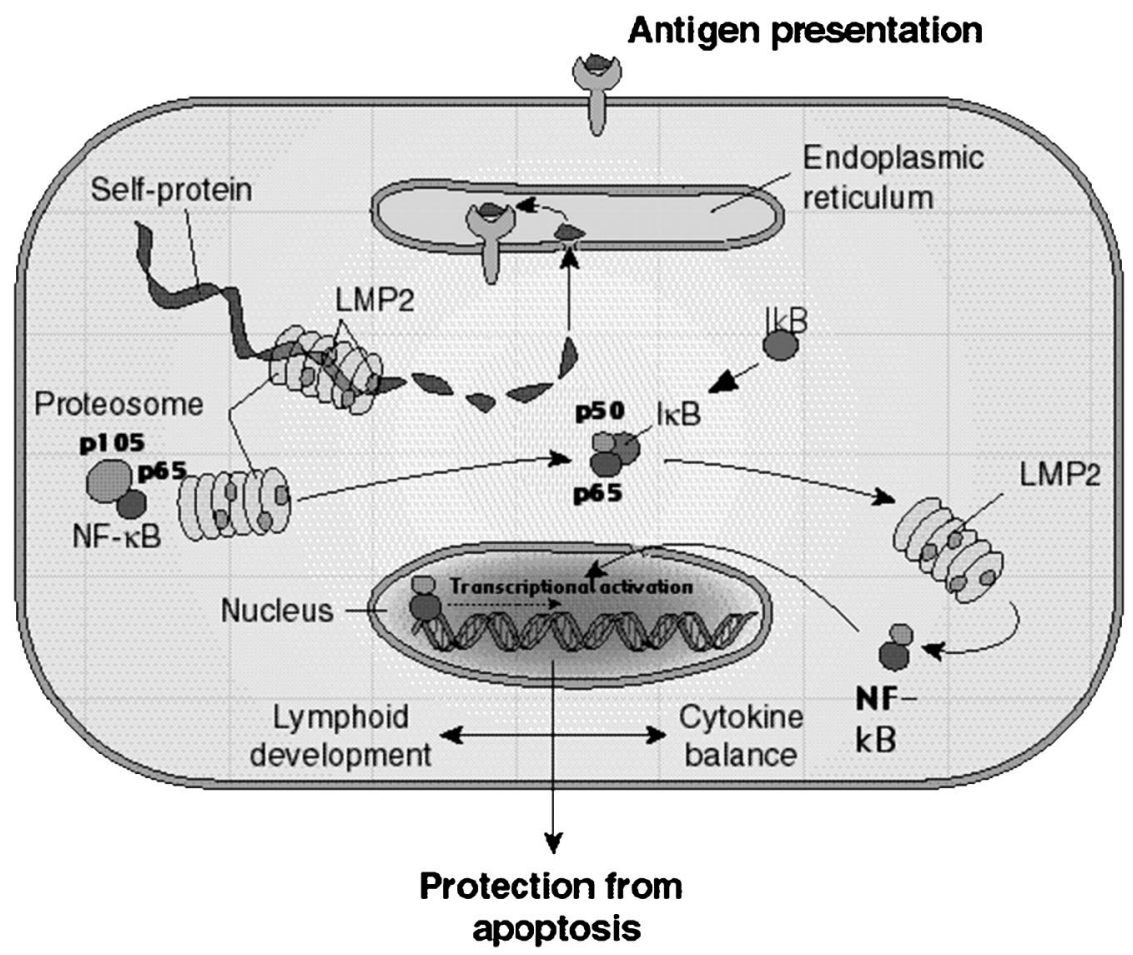

FIG. 5. Impaired expression of LMP2 in NOD mouse splenocytes. (A) Schematic representations of $26 \mathrm{~S}$ and $20 \mathrm{~S}$ proteasomes. (B) Lysates of spleen cells from adult male (M) or female (F) $\mathrm{BALB} / \mathrm{c}$ or NOD mice were subjected to immunoblot analysis with antibodies specific for the indicated $20 \mathrm{~S}$ proteasome subunits or, as controls, with antibodies to various cyclin-dependent kinases (CDKs) or to the transcriptional factor $\mathrm{TAF}_{\mathrm{II}} 250$.

presentation of peptides derived from foreign intracellular proteins, especially viral proteins, for the generation of cytotoxic $\mathrm{T}$ cells. Subsequent studies in transgenic mice deficient in chaperone proteins required for the intracellular assembly of MHC class I complexes confirmed the importance of self-peptide presentation by MHC class I molecules in T-cell education to self (Aldrich et al., 1994; Glas et al., 1994; Van Kaer et al., 1994).

In our attempt to discover the basis for the impairment in presentation of self-peptides by MHC class I molecules in the NOD mouse, we found that the abundance of LMP2 mRNA in lymphoid cells from these animals was markedly reduced, compared with that in control animals. This defect in LMP2 expression 
in the NOD mouse was shown to be attributable, at least in part, to a specific mutation in the shared bidirectional promoter-enhancer region of the LMP2 and TAP1 genes in the MHC class II region of the genome (Figure 2). The reduced abundance of LMP2 interrupts the proteasome-mediated generation of selfpeptides for presentation by MHC class I molecules and the consequent development of T-cell tolerance to self-antigens (Yan et al., 1997). It also prevents the processing of NF- $\kappa \mathrm{B}$ precursor proteins and the degradation of $\mathrm{I} \kappa \mathrm{B} \alpha$ required for activation of NF- $\kappa$ B (Hayashi and Faustman, 1999), events important for T-cell maturation and normal immune and inflammatory responses. The LMP2 expression defect in NOD mice is specific for lymphoid lineage cells and becomes apparent after 10 weeks of age (Hayashi and Faustman, 1999).

The interruption by the LMP2 defect in NOD mice of both self-peptide presentation by APCs as well as normal T-cell development - two phenotypes we had established as important in both murine and human autoimmune diabetes - suggests that the onset of LMP2 downregulation is an essential trigger for disease initiation. The expression of MHC class I molecules in islets is upregulated early during islet invasion by T cells in both humans and NOD mice with type 1 diabetes. This phenomenon probably defines target selection by augmenting self-antigen presentation, thereby promoting cytotoxic $\mathrm{T}$-cell attack mediated by poorly educated, LMP2-deficient T cells.

\section{Increased Sensitivity of NOD Mouse Lymphocytes to TNF- $\alpha$-induced Apoptosis}

Recent reports indicate that NF- $\kappa \mathrm{B}$ is an important protector of cells from TNF- $\alpha$-induced apoptosis (Beg et al., 1995). Embryos of mice lacking the NF- $\kappa \mathrm{B}$ p65 subunit, IKK $\beta$ or IKK $\gamma$, manifest marked hepatic apoptosis that appears to result from the associated defects in NF- $\kappa \mathrm{B}$ activation (Beg and Baltimore, 1996; Li et al., 1999b, Rudolph et al., 2000). The activation of NF $\kappa \mathrm{B}$ by the ubiquitin-proteasome pathway also is thought to protect cells from TNF- $\alpha$-induced cell death (Figure 3) (Beg and Baltimore, 1996; Van Antwerp et al., 1996; Wang et al., 1996; Wu et al., 1996b). The antiapoptotic effect of $\mathrm{NF}-\kappa \mathrm{B}$ is likely mediated by the activation of genes that encode cell survivalpromoting factors.

We investigated the effect of TNF- $\alpha$ on the viability of adult NOD mouse lymphocytes, in which TNF- $\alpha$-induced activation of NF- $\kappa \mathrm{B}$ is impaired. Whereas incubation of $\mathrm{BALB} / \mathrm{c}$ mouse splenocytes with various concentrations (2-20 ng/ml) of TNF- $\alpha$ for 24 hours had virtually no effect on cell survival, TNF- $\alpha$ induced a dose- and time-dependent decrease in the survival of splenocytes derived from male or female NOD mice (Hayashi and Faustman, 1999; Hayashi et al., 2000). Similarly, whereas incubation of BALB/c mouse splenocytes with TNF- $\alpha(10 \mathrm{ng} / \mathrm{ml})$ for up to 48 hours had no effect on cell viability, 
the survival of NOD splenocytes already was reduced markedly after incubation with the same concentration of TNF- $\alpha$ for only 12 hours (Hayashi and Faustman, 1999; Hayashi et al., 2000). The toxic effect of TNF- $\alpha$ on NOD mouse lymphocytes appeared more pronounced for female than for male animals. Exposure of lymphocytes from LMP2 KO mice to TNF- $\alpha$ also resulted in marked cell death (Hayashi and Faustman, 1999; Hayashi et al., 2000). Agarose gel electrophoresis confirmed that TNF- $\alpha$ induced a pattern of internucleosomal DNA fragmentation characteristic of apoptosis in lymphocytes from NOD mice and LMP2 KO, whereas it did not induce DNA fragmentation in those from BALB/c mice (Hayashi and Faustman, 1999). It is thus likely that the toxicity of TNF- $\alpha$ for NOD mouse lymphocytes is attributable to the NF- $\kappa \mathrm{B}$ inactivation due to defective proteasome function.

TNF- $\alpha$ also reduced the viability of spleen cells derived from 7-day-old NOD mice but to a lesser extent than it did in cells derived from adult animals. It had no effect on the viability of spleen cells derived from 7-day-old BALB/c mice. Whereas TNF- $\alpha$ had no effect on the viability of cultured macrophages derived from 13.5-day BALB/c or NOD mouse fetal liver, it induced a dose- and time-dependent decrease in the viability of such cells derived from LMP2 KO mouse fetal liver at the same stage of development (Hayashi and Faustman, 1999). Similarly, TNF- $\alpha$ had no effect on the viability of cultured BALB/c or NOD mouse embryonic fibroblasts, whereas TNF- $\alpha$ treatment of such cells derived from LMP2 KO mice resulted in prominent cell death (Hayashi and Faustman, 1999,2000). Although disruption of the NF- $\kappa$ B p65, IKK $\beta$, or IKK $\gamma$ genes is associated with marked abnormalities in liver development (Beg et al., 1995; Beg and Baltimore, 1996; Li et al., 1999b; Rudolph et al., 2000), hematoxylin-eosin staining of liver sections from 6-week-old NOD mice did not reveal any apparent defects (Hayashi and Faustman, 1999).

\section{Impaired Granulocyte-Macrophage Colony Formation by NOD Mouse Spleen Cells}

NF- $\kappa \mathrm{B}$ also plays an important role in the maturation of lymphocytes and monocytes. We therefore examined the development of the granulocytemacrophage (GM) cell lineage with splenocytes isolated from 6-week-old NOD and BALB/c mice. Colony-formation assays revealed that, whereas GM-colonystimulating factor (CSF) induced the formation of clusters of mature GMs in BALB/c mouse splenocytes, the formation of such clusters was impaired in splenocytes from NOD mice (Figure 4, A-D). Furthermore, whereas exposure of GM-CSF-treated spleen cell cultures from BALB/c mice to TNF- $\alpha$ had no effect on cell viability or colony development, TNF- $\alpha$ induced the death of all cells in NOD mouse cultures (Figure 4, E-H). 
The specificity of the developmental defect and cytotoxic effect of TNF- $\alpha$ in the GM lineage of NOD mice was investigated by examining colony-forming units (CFUs) of erythrocytes in cultures of spleen cells derived from 6-week-old $\mathrm{BALB} / \mathrm{c}$ and NOD animals. Erythrocyte colony formation appeared normal in erythropoietin-supplemented cultures of NOD mouse spleen cells, compared to that observed in spleen cells from BALB/c mice (Hayashi and Faustman, 1999). Moreover, TNF- $\alpha$ had no effect on erythrocyte colony formation, which is known to require NF- $\kappa$ B, in spleen cells from either BALB/c or NOD mice. These results suggest that a lack of NF- $\kappa \mathrm{B}$ activation in GM precursors derived from NOD mice at 6 weeks of age impairs the maturation of these cells and renders them susceptible to the cytotoxic effect of TNF- $\alpha$. In contrast, NF- $\kappa$ B appears to be functional in the erythrocyte lineage of these mice, which seem to develop normally and be resistant to TNF- $\alpha$-induced apoptosis. Given that TNF- $\alpha$ had no effect on the viability of cultured macrophages derived from 13.5-day BALB/c or NOD mouse fetal liver, the proteasome defect in NOD mice appears to be specific for both cell type and developmental stage.

\section{Gender, Age, and Tissue Specificity of Proteasome Dysfunction and Disease Expression in NOD Mice}

The prevalence of diabetes is markedly greater in NOD females than in NOD males. Most human autoimmune diseases also are expressed preferentially in females. Consistent with a role for defective proteasome activity and consequent impaired NF- $\kappa$ B function in NOD mouse diabetes, cytosolic extracts of splenocytes from male NOD mice were able to convert a small proportion of recombinant NF- $\kappa \mathrm{B}$ p105 to $\mathrm{p} 50$. However, the product of this reaction appeared to differ in size slightly from that of the p50 subunit produced by extracts of BALB/c mice (Hayashi and Faustman, 1999). Splenocyte extracts from NOD females did not generate any detectable p50 protein in this assay. Furthermore, as mentioned previously, both the time course and dose-response relation for the effect of TNF- $\alpha$ on cell viability revealed that the sensitivity of splenocytes from NOD females to this cytokine was greater than that of cells from NOD males (Hayashi and Faustman, 1999; Hayashi et al., 2000).

The characteristics of KO mice that lack NF- $\kappa$ B subunits or LMP2 overlap partially with those of NOD mice (Van Kaer et al., 1994; Burkly et al., 1995; Kontgen et al., 1995; Weih et al., 1995; Horwitz et al., 1997). However, LMP2-deficient mice do not develop diabetes by 32 weeks of age (D.L. Faustman, unpublished observation), consistent with the contribution of multiple chromosomal regions to disease penetrance in both NOD mice and humans. The homogeneous nature of the gene defect in all tissues of LMP2 KO mice differs from the apparent developmental stage and tissue specificity of the proteasome defect in NOD mice, which might underlie target selection in disease expression. 
LMP2-deficient and other KO mice with defects in the assembly of MHC class I molecules with self-peptides destroy transplanted syngeneic tissues from control animals (Li and Faustman, 1993; Vidal-Puig and Faustman, 1994; Freland et al., 1998). Target cell loss thus might result from preferential direct attack by cytotoxic $\mathrm{T}$ lymphocytes in the early stages of autoimmune disease.

The marked proapoptotic effect of TNF- $\alpha$ in NOD mouse lymphocytes also suggested a possible role for this cytokine in early $\beta$-cell destruction in these animals. Such a mechanism of $\beta$-cell death would require that $\beta$ cells exhibit the same proteasome defect as that apparent in NOD mouse lymphocytes. This defect is characterized by loss of LMP 2 expression, aberrant NF- $\kappa \mathrm{B}$ activation, increased sensitivity to the cytotoxic effect of TNF- $\alpha$, and reduced expression of peptide-filled MHC class I molecules on the cell surface. However, one of the early pathological features of autoimmune diabetes in both humans and rodent models is hyperexpression of correctly assembled MHC class I molecules on the surface of $\beta$ cells (Foulis, 1987; Ono et al., 1988; Weringer and Like, 1988; Hanafusa et al., 1990; Kay et al., 1991; Vivés-Pi et al., 1996; Stephens et al., 1997), a phenomenon that requires intact proteasome function. Studies of both humans and animals with diabetes or other autoimmune diseases suggest that discordance in the regulation of MHC-linked genes between tissues might confer target specificity for attack by cytotoxic T lymphocytes (Hayashi and Faustman, 1999).

Macrophages and fibroblasts derived from 13.5-day NOD mouse embryos exhibited normal cell growth and resistance to TNF- $\alpha$ cytotoxicity. In contrast, TNF- $\alpha$ exhibited a marked proapoptotic effect in the corresponding cell types derived from LMP2 KO mice (Hayashi and Faustman, 1999,2000; Hayashi et al., 2000). TNF- $\alpha$ also induced a relatively small decrease in the viability of spleen cells derived from 7-day-old NOD mice but had no such effect on the corresponding cells from BALB/c mice. In contrast, lymphoid cells of splenic origin, lung macrophages (Kupffer cells), and GMs from 6- to 8-week-old NOD mice exhibit reduced LMP2 expression, impaired NF- $\kappa \mathrm{B}$ activation, and increased sensitivity to the cytotoxic effect of TNF- $\alpha$ (Hayashi and Faustman, 1999). Furthermore, consistent with a role for the proteasome and NF- $\kappa \mathrm{B}$ in normal cell growth, culture of spleen cells from 6-week-old NOD mice with GM-CSF failed to induce normal expansion of the GM cell lineage. The islets of Langerhans, liver, and erythrocytes of 6- to 8-week-old NOD mice appear normal. The ability of NOD mouse macrophages to activate regulatory $\mathrm{T}$ cells in an autologous mixed lymphocyte reaction also has been shown to be impaired (Atkinson and Leiter, 1999).

The age-dependent proteasome defect in the macrophages of NOD mice likely explains some of the important features of disease development in these animals. Thus, female NOD mice show no signs of autoimmunity up to 3 weeks of age. At 5 weeks and older, insulitis begins to appear. By 8 weeks of age, 
autoantibodies are detectable. The insulitis gradually increases in intensity, with complete destruction of islets usually apparent by 30 weeks of age (Makino et al., 1980). Furthermore, the outcomes of various interventions and treatments in NOD mice are age dependent. For instance, the administration of TNF- $\alpha$ to animals older than 6 weeks sometimes prevents the development of diabetes, whereas the same treatment in animals younger than 4 weeks has no effect or a detrimental effect (Yang et al., 1994). Therefore, both the time course of the histopathology of autoreactivity and the paradoxical responses to TNF- $\alpha$ treatment parallel the altered developmental regulation of LMP2 expression and $\mathrm{NF}-\kappa \mathrm{B}$ activity in these animals.

\section{Defective Proteasome Function and Autoimmunity}

The ubiquitin-proteasome pathway plays an essential role in many important biological processes (Maniatis, 1999). Protein degradation by this pathway thus generates peptides for presentation by MHC class I molecules and either activates or inactivates transcription factors. In general, proteasome subunit composition varies minimally among eukaryotic cells. However, the interferon$\gamma$-induced expression of the MHC-encoded proteasome subunits LMP2 and LMP7 is thought to promote the generation of endogenous peptides compatible with the peptide-binding cleft of MHC class I molecules (Akiyama et al., 1994; Belich et al., 1994). The MHC-encoded proteasome subunits also play a role in general proteasome function, including the processing and activation of NF- $\kappa \mathrm{B}$.

The defect in proteasome function in NOD mouse splenocytes is attributable to a loss of expression of the LMP2 subunit and was evident from the impaired proteolytic processing of the p105 precursor of the NF- $\kappa \mathrm{B}$ subunit p50 in vitro as well as from the lack of degradation of phosphorylated $\mathrm{I} \kappa \mathrm{B} \alpha$ in these cells in response to TNF- $\alpha$. This defect confers sensitivity on the affected cells to the apoptotic action of TNF- $\alpha$ (Figure 6). The role of LMP2 in NF- $\kappa$ B activation was confirmed by observations that 1) cytosolic extracts of lymphocytes from LMP2 KO mice also failed to convert p105 to p50 and 2) only NOD mouse tissues that lack LMP2 subunit showed impaired activation of NF- $\kappa \mathrm{B}$ and sensitivity to TNF- $\alpha$-induced apoptosis (Hayashi and Faustman, 1999,2000). The defect in LMP2 protein production in NOD mice is both developmental stage (age) and tissue specific. Dysfunction of a gene in the $\mathrm{MHC}$ region of the genome thus virtually abolishes the activity of a transcription factor that plays important roles in both immune and nonimmune cellular functions. The NOD mouse therefore represents a newly defined mosaic model of discordant $\mathrm{MHC}$ gene expression that exhibits marked proteasome dysfunction in an age- and tissue-specific manner.

The delayed maturation of lymphocytes and cytokine abnormalities apparent in NOD mice that spontaneously develop type 1 diabetes are mirrored, in part, by 


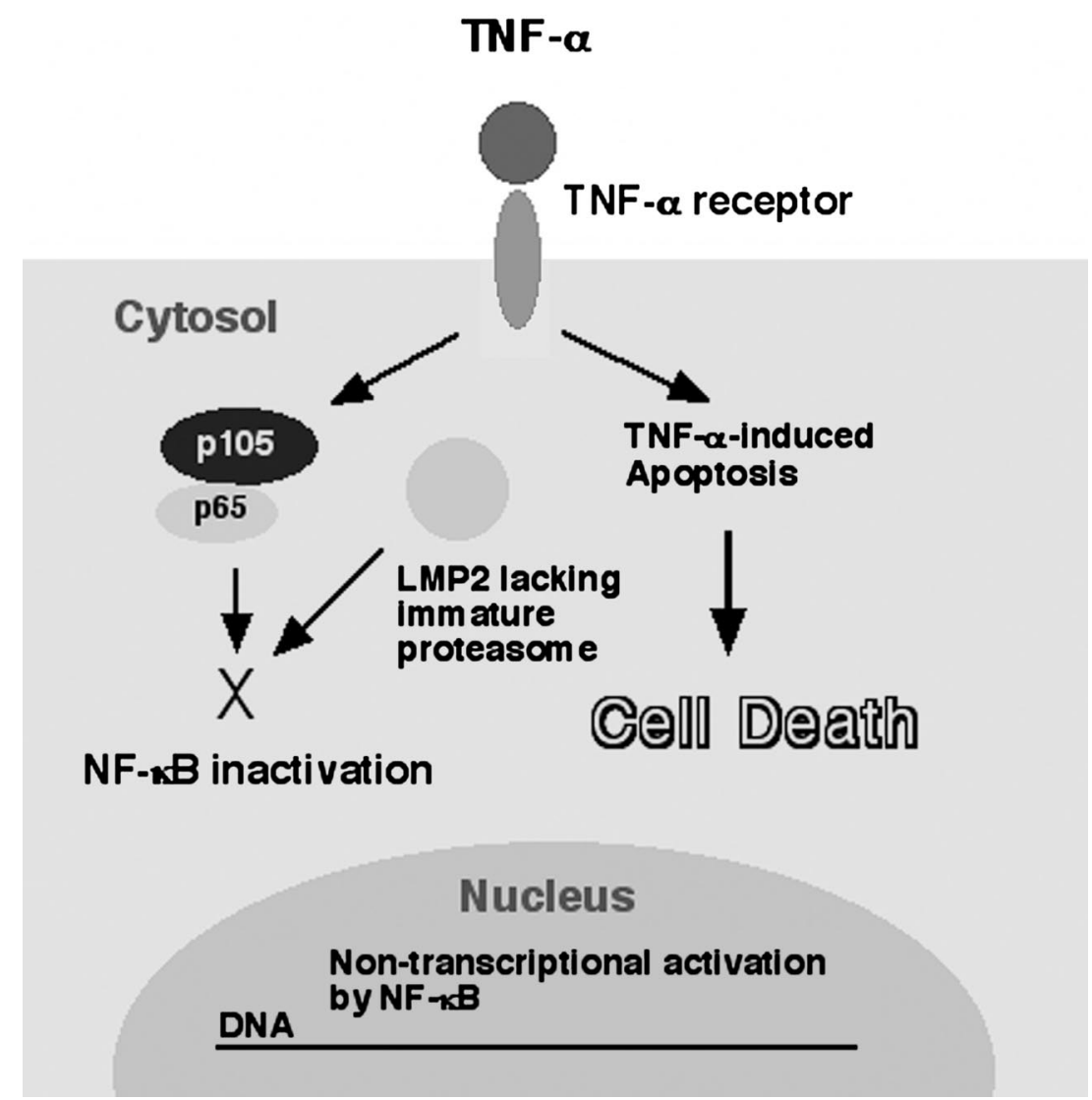

FIG. 6. Model for TNF- $\alpha$-induced apoptosis in NOD mouse lymphocytes. The TNF- $\alpha$ signaling pathway generates an unknown proapoptotic signal. The defect in the activation of NF- $\kappa$ B prevents induction of the expression of a gene (or genes) that encodes an antiapoptotic factor (or factors), resulting in an increased susceptibility to apoptosis.

the phenotypes of KO mice lacking NK- $\kappa$ B subunits or LMP2 (Van Kaer et al., 1994; Sha et al., 1995; Beg and Baltimore, 1996; Snapper et al., 1996; Franzoso et al., 1997; Horwitz et al., 1997; Iotsova et al., 1997; Caamano et al., 1998; Tanaka et al., 1999). The clinical relevance of the phenotypes of the NOD mouse and of these various $\mathrm{KO}$ animals to human disease is supported by the existence of nearly identical cytokine and lymphocyte maturation defects in humans with type 1 diabetes.

In conclusion, we have demonstrated the existence of a marked defect in proteasome function in lymphocytes from autoimmune diabetes-prone NOD 
mice. This defect results from a deficiency of the LMP2 subunit, which is encoded by a gene located in the MHC region of the genome. It results in both impaired processing of self-peptides for presentation by MHC class I molecules as well as the inability to activate NF- $\kappa$ B. A similar age-related defect in GMs is proposed to confer target specificity in autoimmunity toward tissues with intact LMP2 expression. Abnormal processing of intracellular proteins thus may contribute to the pathogenesis of type 1 diabetes.

\section{REFERENCES}

Akiyama K, Yokota K, Kagawa S, Shimbara N, Tamura T, Akioka H, Nothwang HG, Noda C, Tanaka K, Ichihara A 1994 cDNA cloning and interferon $\gamma$ down-regulation of proteasomal subunits X and Y. Science 265:1231-1234

Aldrich CJ, Ljunggren HG, Van Kaer L, Ashton-Rickardt PG, Tonegawa S, Forman J 1994 Positive selection of self- and alloreactive $\mathrm{CD}^{+} \mathrm{T}$ cells in TAP-1 mutant mice. Proc Natl Acad Sci USA 91:6525-6528

Allen RD, Marshall JD, Roths JB, Sidman CL 1990 Differences defined by bone marrow transplantation suggest that $l p r$ and $g l d$ are mutations of genes encoding an interacting pair of molecules. J Exp Med 172:1367-1375

Amrani A, Verdaguer J, Anderson B, Utsugi T, Bou S, Santamaria P 1999 Perforin-independent beta-cell destruction by diabetogenic $\mathrm{CD}^{+} \mathrm{T}$ lymphocytes in transgenic nonobese diabetic mice. J Clin Invest 103:1201-1209

Atkinson MA, Leiter EH 1999 The NOD mouse model of type 1 diabetes: as good as it gets? Nat Med 5:601-604

Baeuerle PA, Baltimore D 1996 NF- $\kappa$ B: ten years after. Cell 87:13-20

Baldwin AS 1996 The NF- $\kappa$ B and I $\kappa$ B proteins: new discoveries and insights. Annu Rev Immunol 12:141-179

Becker KG, Simon RM, Bailey-Wilson JE, Freidlin B, Biddison WE, McFarland HF, Trent JM 1998 Clustering of non-major histocompatibility complex susceptibility candidate loci in human autoimmune diseases. Proc Natl Acad Sci USA 95:9979-9984

Beg AA, Baltimore D 1996 An essential role for NF- $\kappa$ B in preventing TNF- $\alpha$-induced cell death. Science 274:782-784

Beg AA, Sha WC, Bronson RT, Ghosh S, Baltimore D 1995 Embryonic lethality and liver degeneration in mice lacking the relA component of NF- $\kappa$ B. Nature 376:167-170

Belich MP, Glynne RJ, Senger G, Sheer D, Trowsdale J 1994 Proteasome components with reciprocal expression to that of the MHC-encoded LMP proteins. Curr Biol 4:769-776

Belich MP, Salmeron A, Johnston LH, Ley SC 1999 TPL-2 kinase regulates the proteolysis of the NF- $\kappa$ B-inhibitory protein NF- $\kappa$ B1 p105. Nature 397:363-368

Bohnline E, Lowenthal JW, Siekevitz M, Franza BR, Greene WC 1988 The same inducible nuclear protein regulates mitogen activation of both the interleukin- 2 receptor- $\alpha$ gene and type 1 HIV. Cell 53:827-836

Burkly L, Hession C, Ogata L, Reilly C, Marconi LA, Olson D, Tizard R, Cate R, Lo D 1995 Expression of relB is required for the development of thymic medulla and dendritic cells. Nature 373:531-536

Bushdid PB, Brantley DM, Yull FE, Blaeuer GL, Hoffman LH, Niswander L, Kerr LD 1998 Inhibition of NF- $\kappa \mathrm{B}$ activity results in disruption of the apical ectodermal ridge and aberrant limb morphogenesis. Nature 392:615-618 
Caamano JH, Rizzo CA, Durham SK, Barton DS, Raventos-Suarez C, Snapper CM, Bravo R 1998 Nuclear factor (NF) $-\kappa$ B2 (p100/p52) is required for normal splenic microarchitecture and B cell-mediated immune responses. J Exp Med 187:185-196

Chervonsky AV, Wang Y, Wong FS, Visintin I, Flavell RA, Janeway CA Jr, Matis LA 1997 The role of Fas in autoimmune diabetes. Cell 89:17-24

Coux O, Goldberg AL 1998 Enzymes catalyzing ubiquitination and proteolytic processing of the p105 precursor of nuclear factor $\kappa$ B1. J Biol Chem 273:8820-8828

Coux O, Tanaka K, Goldberg AL 1996 Structure and functions of the 20S and 26S proteasomes. Annu Rev Biochem 65:801-847

Crisa L, Mordes JP, Rossini AA 1992 Autoimmune diabetes mellitus in the BB rat. Diabetes Metab Rev 8:9-37

Cross SL, Halden NF, Lenardo M, Leonard WJ 1989 Functionally distinct NF- $\kappa$ B binding sites in the immunoglobulin $\kappa$ and IL-2 receptor $\alpha$ chain genes. Science 244:466-468

Delovitch TL, Singh B 1997 The nonobese diabetic mouse as a model of autoimmune diabetes: immune dysregulation gets the NOD [published erratum appears in Immunity 1998;8:531]. Immunity 7:727-738

Desai-Mehta A, Lu L, Ramsey-Goldman R, Datta SK 1996 Hyperexpression of CD40 ligand by $\mathrm{B}$ and $\mathrm{T}$ cells in human lupus and its role in pathogenic autoantibody production. J Clin Invest 97:2063-2073

Drappa J, Vaishnaw AK, Sullivan KE, Chu JL, Elkon KB 1996 Fas gene mutations in the Canale-Smith syndrome, an inherited lymphoproliferative disorder associated with autoimmunity [see comments]. N Engl J Med 335:1643-1649

Emlen W, Niebur J, Kadera R 1994 Accelerated in vitro apoptosis of lymphocytes from patients with systemic lupus erythematosus. J Immunol 152:3685-3692.

Fan CM, Maniatis T 1991 Generation of p50 subunit of NF- $\kappa$ B by processing of p105 through an ATP-dependent pathway. Nature 354:395-398

Faustman D, Eisenbarth G, Daley J, Breitmeyer J 1989 Abnormal T lymphocyte subsets in type I diabetes mellitus: analysis with anti-2H4 and anti-4B4 antibodies. Diabetes 38:1462-1468

Faustman D, Li X, Lin HY, Fu Y, Eisenbarth G, Avruch J, Guo J 1991 Linkage of faulty major histocompatibility complex class I to autoimmune diabetes. Science 254:1756-1761

Foulis AK 1987 The pathogenesis of beta cell destruction in type I (insulin-dependent) diabetes mellitus. J Pathol 152:141-148

Franzoso G, Carlson L, Xing L, Poljak L, Shores EW, Brown KD, Leonardi A, Tran T, Boyce BF, Siebenlist U 1997 Requirement for NF- $\kappa$ B in osteoclast and B-cell development. Genes Dev 11:3482-3496

Freland S, Chambers BJ, Andersson M, Van Kaer L, Ljunggren HG 1998 Rejection of allogeneic and syngeneic but not MHC class I-deficient tumor grafts by MHC class I-deficient mice. J Immunol 160:572-579

Fruh K, Yang Y, Arnold D, Chambers J, Wu L, Waters JB, Spies T, Peterson PA 1992 Alternative exon usage and processing of the major histocompatibility complex-encoded proteasome subunits. J Biol Chem 267:22131-22140

Fu Y, Nathan DM, Li F, Li X, Faustman DL 1993 Defective major histocompatibility complex class I expression on lymphoid cells in autoimmunity. J Clin Invest 9 1:2301-2307

Gaczynska M, Goldberg AL, Tanaka K, Hendil KB, Rock KL 1996 Proteasome subunits X and $\mathrm{Y}$ alter peptidase activities in opposite ways to the interferon- $\gamma$-induced subunits LMP2 and LMP7. J Biol Chem 27 1:17275-17280

Ghosh S, Baltimore D 1990 Activation in vitro of NF- $\kappa$ B by phosphorylation of its inhibitor I $\kappa$ B. Nature 344:678-682 
Glas R, Ohlen C, Hoglund P, Karre K 1994 The CD8 ${ }^{+}$T cell repertoire in $\beta_{2}$-microglobulindeficient mice is biased towards reactivity against self-major histocompatibility class I. J Exp Med 179:661-672

Goldberg AL 1995 Functions of the proteasome: the lysis at the end of the tunnel [see comment]. Science 268:522-523

Griffin TA, Nandi D, Cruz M, Fehling HJ, Kaer LV, Monaco JJ, Colbert RA 1998 Immunoproteasome assembly: cooperative incorporation of interferon $\gamma$ (IFN- $\gamma$ )-inducible subunits. J Exp Med 187:97-104

Hanafusa T, Miyazaki A, Miyagawa J, Tamura S, Inada M, Yamada K, Shinji Y, Katsura H, Yamagata K, Itoh N 1990 Examination of islets in the pancreas biopsy specimens from newly diagnosed type 1 (insulin-dependent) diabetic patients. Diabetologia 33:105-111

Hayashi T, Faustman D 1999 NOD mice are defective in proteasome production and activation of NF- $\kappa$ B. Mol Cell Biol 19:8646-8659

Hayashi T, Faustman D 2000 Essential role of HLA-encoded proteasome subunits in NF- $\kappa$ B activation and prevention of TNF- $\alpha$-induced apoptosis. J Biol Chem 275:5238-5247

Hayashi T, Sekine T, Okamoto T 1993a Identification of a new serine kinase that activates NF $\kappa$ B by direct phosphorylation. J Biol Chem 268:26790-26795

Hayashi T, Ueno Y, Okamoto T 1993b Oxireductive regulation of nuclear factor $\kappa \mathrm{B}$, involvement of a cellular reducing catalyst thioredoxin. J Biol Chem 268:11380-11388

Hayashi T, Kodama S, Faustman D 2000 LMP2 expression and proteasome activity in NOD mice. Nat Med 6:1064-1066

Hisamatsu H, Shimbara N, Saito Y, Kristensen P, Hendil KB, Fujiwara T, Takahashi E, Tanahashi N, Tamura T, Ichihara A, Tanaka K 1996 Newly identified pair of proteasomal subunits regulated reciprocally by interferon- $\gamma$. J Exp Med 183:1807-1816

Horwitz BH, Scott ML, Cherry SR, Bronson RT, Baltimore D 1997 Failure of lymphopoiesis after adoptive transfer of NF- $\kappa \mathrm{B}$-deficient fetal liver cells. Immunity 6:765-772

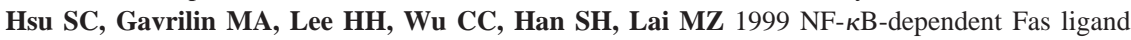
expression. Eur J Immunol 29:2948-2956

Hu Y, Baud V, Delhase M, Zhang P, Deerinck T, Ellisman M, Johnson R, Karin M 1999 Abnormal morphogenesis but intact IKK activation in mice lacking the IKK $\alpha$ subunit of I $\kappa \mathrm{B}$ kinase [see comments]. Science 284:316-320

Iotsova V, Caamano J, Loy J, Yang Y, Lewin A, Bravo R 1997 Osteopetrosis in mice lacking NF- $\kappa$ B1 and NF- $\kappa$ B2. Nat Med 3:1285-1289

Itoh N, Imagawa A, Hanafusa T, Waguri M, Yamamoto K, Iwahashi H, Moriwaki M, Nakajima H, Miyagawa J, Namba M, Makino S, Nagata S, Kono N, Matsuzawa Y 1997 Requirement of Fas for the development of autoimmune diabetes in nonobese diabetic mice. J Exp Med 186:613-618

Jansen A, Van Hagen M, Drexhage HA 1995 Defective maturation and function of antigenpresenting cells in type I diabetes. Lancet 345:491-492

Kanegae Y, Tavares AT, Izpisua Belmonte JC, Verma IM 1998 Role of Rel/NF- $\kappa$ B transcription factors during the outgrowth of the vertebrate limb. Nature 392:611-614

Kang SM, Schneider DB, Lin Z, Hanahan D, Dichek DA, Stock PG, Baekkeskov S 1997 Fas ligand expression in islets of Langerhans does not confer immune privilege and instead targets them for rapid destruction [see comments]. Nat Med 3:738-743

Kang SM, Lin Z, Ascher NL, Stock PG 1998 Fas ligand expression on islets as well as multiple cell lines results in accelerated neutrophilic rejection. Transplant Proc 30:538

Kay TWH, Campbell IL, Oxbrow L, Harrison LC 1991 Overexpression of class I major histocompatibiity complex accompanies insulitis in the nonobese diabetic mouse and is prevented by anti-interferon- $\gamma$ antibody. Diabetologia 34:779-785 
Kim S, Kim KA, Hwang DY, Lee TH, Kayagaki N, Yagita H, Lee MS 2000 Inhibition of autoimmune diabetes by Fas ligand: the paradox is solved. J Immunol 164:2931-2936

Kim YH, Kim S, Kim KA, Yagita H, Kayagaki N, Kim KW, Lee MS 1999 Apoptosis of pancreatic beta-cells detected in accelerated diabetes of NOD mice: no role of Fas-Fas ligand interaction in autoimmune diabetes. Eur J Immunol 29:455-465

Kontgen F, Grumont RJ, Strasser A, Metcalf D, Li R, Tarlinton D, Gerondakis S 1995 Mice lacking the c-rel proto-oncogene exhibit defects in lymphocyte proliferation, humoral immunity, and interleukin-2 expression. Genes Dev 9:1965-1977

Koshy M, Berger D, Crow MK 1996 Increased expression of CD40 ligand on systemic lupus erythematosus lymphocytes. J Clin Invest 98:826-837

Kovacs B, Liossis SN, Dennis GJ, Tsokos GC 1997 Increased expression of functional Fas-ligand in activated T cells from patients with systemic lupus erythematosus. Autoimmunity 25:213221

Lamhamedi-Cherradi SE, Luan JJ, Eloy L, Fluteau G, Bach JF, Garchon HJ 1998 Resistance of T-cells to apoptosis in autoimmune diabetic (NOD) mice is increased early in life and is associated with dysregulated expression of Bcl-x. Diabetologia 41:178-184

Li F, Hauser SL, Linan MJ, Stein MC, Faustman DL 1995 Reduced expression of peptideloaded HLA class I molecules on multiple sclerosis lymphocytes. Ann Neurol 38:147-154

Li Q, Lu Q, Hwang JY, Buscher D, Lee KF, Izpisua-Belmonte JC, Verma IM 1999a IKK1deficient mice exhibit abnormal development of skin and skeleton. Genes Dev 13:13221328

Li Q, Van Antwerp D, Mercurio F, Lee KF, Verma IM 1999b Severe liver degeneration in mice lacking the I $\kappa$ B kinase 2 gene [see comments]. Science 284:321-325

Li X, Faustman D 1993 Use of donor $\beta_{2}$-microglobulin-deficient transgenic mouse liver cells for isografts, allografts, and xenografts. Transplantation 55:940-946

Liang H, Fesik SW 1997 Three-dimensional structures of proteins involved in programmed cell death. J Mol Biol 274:291-302

Lin J, Tserng K, Chen C, Lin L, Tung T 1970 Abrin and ricin: new anti-tumor substances. Nature 227:562-563

Lin L, DeMartino GN, Greene WC 1998 Co-translational biogenesis of NF- $\kappa$ B p50 by the 26S proteasome. Cell 92:819-828

Lorenz HM, Grunke M, Hieronymus T, Herrmann M, Kuhnel A, Manger B, Kalden JR 1997 In vitro apoptosis and expression of apoptosis-related molecules in lymphocytes from patients with systemic lupus erythematosus and other autoimmune diseases [see comments]. Arthritis Rheum 40:306-317

Lynch DH, Watson ML, Alderson MR, Baum PR, Miller RE, Tough T, Gibson M, Davis-Smith T, Smith CA, Hunter K 1994 The mouse Fas-ligand gene is mutated in gld mice and is part of a TNF family gene cluster. Immunity 1:131-136

MacKichan ML, Logeat F, Israel A 1996 Phosphorylation of p105 PEST sequences via a redox-insensitive pathway up-regulates processing of p50 NF- $\kappa$ B. J Biol Chem 271:60846091

Makino S, Kunimoto K, Muraoka Y, Mizushima Y, Katagiri K, Tochino Y 1980 Breeding of a non-obese, diabetic strain of mice. Jikken Dobutsu Exp Animals 29:1-13

Maniatis T 1999 A ubiquitin ligase complex essential for the NF- $\kappa$ B, Wnt/Wingless, and Hedgehog signaling pathways.Genes Dev 13:505-510

Mountz JD, Zhou T, Su X, Cheng J, Pierson M, Bluethmann H, Edwards CK III 1996 Autoimmune disease results from multiple interactive defects in apoptosis induction molecules and signaling pathways. Behring Inst Mitteilungen 6:200-219

Mysler E, Bini P, Drappa J, Ramos P, Friedman SM, Krammer PH, Elkon KB 1994 The apoptosis-1/Fas protein in human systemic lupus erythematosus. J Clin Invest 93:1029-1034 
Oeri A, Chang CC, Lombardi L, Salina M, Corradini P, Maiolo AT, Chaganti RS, Dalla-Favera R 1991 B cell lymphoma-associated chromosomal translocation involves candidate oncogene lyt-10, homologous to NF- $\kappa$ B p50. Cell 67:1075-1087

Ono SJ, Issa-Chergui B, Colle E, Guttmann RD, Seemayer TA, Fuks A 1988 IDDM in BB rats. Enhanced MHC class I heavy-chain gene expression in pancreatic islets. Diabetes 37:14111418

Pakala SV, Chivetta M, Kelly CB, Katz JD 1999 In autoimmune diabetes the transition from benign to pernicious insulitis requires an islet cell response to tumor necrosis factor $\alpha$. J Exp Med 189:1053-1062

Palombella V, Rando OJ, Goldberg AL, Maniatis T 1994 The ubiquitin-proteasome pathway is required for processing the NF- $\kappa \mathrm{B} 1$ precursor protein and the activation of NF- $\kappa \mathrm{B}$. Cell 78:773-785

Quaaz F, Li M, Beg AA 1999 A critical role for the RelA subunit of nuclear factor $\kappa$ B in regulation of multiple immune-response genes and in Fas-induced cell death. J Exp Med 189:999-1004

Rabinovitch A 1998 An update on cytokines in the pathogenesis of insulin-dependent diabetes mellitus. Diabetes Metab Rev 14:129-151

Rabinovitch A, Skyler JS 1998 Prevention of type 1 diabetes. Med Clin N Am 82:739-755

Ramsdell F, Seaman MS, Miller RE, Tough TW, Alderson MR, Lynch DH 1994 gld/gld mice are unable to express a functional ligand for Fas. Eur J Immunol 24:928-933

Restifo NP 2000 Not so Fas: re-evaluating the mechanisms of immune privilege and tumor escape. Nat Med 6:493-495

Rieux-Laucat F, Le Deist F, Hivroz C, Roberts IA, Debatin KM, Fischer A, de Villartay JP 1995 Mutations in Fas associated with human lymphoproliferative syndrome and autoimmunity. Science 268:1347-1349

Rudolph D, Yeh WC, Wakeham A, Rudolph B, Nallainathan D, Potter J, Elia AJ, Mak TW 2000 Severe liver degeneration and lack of NF- $\kappa \mathrm{B}$ actvation in NEMO/IKK $\gamma$-deficient mice. Genes Dev 14:854-862

Schmid RM, Perkins ND, Duckett CS, Andrews PC, Nabel GJ 1991 Cloning of an NF- $\kappa$ B subunit which stimulates HIV transcription in synergy with p65. Nature 352:733-736

Sears C, Olesen J, Rubin D, Finley D, Maniatis T 1998 NF- $\kappa$ B p105 processing via the ubiquitin-proteasome pathway. J Biol Chem 273:1409-1419

Sha WC, Liou HC, Tuomanen El, Baltimore D 1995 Targeted disruption of the p50 subunit of $\mathrm{NF}-\kappa \mathrm{B}$ leads to multifocal defects in immune responses. Cell 80:321-330

Smerdon RA, Peakman M, Hussain MJ, Alviggi L, Watkins PJ, Leslie RD, Vergani D 1993 Increase in simultaneous coexpression of naive and memory lymphocyte markers at diagnosis of IDDM. Diabetes 42:127-133

Snapper CM, Zelazowski P, Rosas FR, Kehry MR, Tian M, Baltimore D, Sha WC 1996 B cells from $\mathrm{p} 50 / \mathrm{NF}-\kappa \mathrm{B}$ knockout mice have selective defects in proliferation, differentiation, germ-line $\mathrm{C}_{\mathrm{H}}$ transcription, and Ig class switching. J Immunol 156:183-191

Stephens LA, Thomas HE, Kay TW 1997 Protection of NIT-1 pancreatic beta-cells from immune attack by inhibition of NF- $\kappa$ B. J Autoimmunity 10:293-298

Suarez-Pinzon W, Sorensen O, Bleackley RC, Elliott JF, Rajotte RV, Rabinovitch A 1999 Beta-cell destruction in NOD mice correlates with Fas (CD95) expression on beta-cells and proinflammatory cytokine expression in islets. Diabetes 48:21-28

Sun SC, Ganchi PA, Beraud C, Ballard DW, Greene WC 1994 Autoregulation of the NF- $\kappa$ B transactivator RelA (p65) by multiple cytoplasmic inhibitors containing ankyrin motifs. Proc Natl Acad Sci USA 91:1346-1350

Takahashi T, Tanaka M, Brannan CI, Jenkins NA, Copeland NG, Suda T, Nagata S 1994 Generalized lymphoproliferative disease in mice, caused by a point mutation in the Fas ligand. Cell 76:969-976 
Takeda K, Takeuchi O, Tsujimura T, Itami S, Adachi O, Kawai T, Sanjo H, Yoshikawa K, Terada N, Akira S 1999 Limb and skin abnormalities in mice lacking IKK $\alpha$ [see comments]. Science 284:313-316

Tan TH, Huang GP, Sica A, Ghosh P, Young HA, Longo DL, Rice NR $1992 \kappa$ B site dependent activation of the interleukin- 2 receptor $\alpha$-chain gene promoter by human c-Rel. Mol Cell Biol 12:4067-4075

Tanaka M, Fuentes ME, Yamaguchi K, Durnin MH, Dalrymple SA, Hardy KL, Goeddel DV 1999 Embryonic lethality, liver degeneration, and impaired NF- $\kappa$ B activation in IKK- $\beta$ deficient mice. Immunity 10:421-429

Thanos D, Maniatis T 1995 NF- $\kappa$ B: a lesson in family values. Cell 80:529-532

Thomas HE, Darwiche R, Corbett JA, Kay TW 1999 Evidence that beta cell death in the nonobese diabetic mouse is Fas independent. J Immunol 163:1562-1569

Van Antwerp DJ, Martin SJ, Kafri T, Green DR, Verma IM 1996 Suppression of TNF- $\alpha$-induced apoptosis by NF- $\kappa$ B. Science 274:787-789

Van Kaer L, Ashton-Rickardt PG, Eichelberger M, Gaczynska M, Nagashima K, Rock KL, Goldberg AL, Doherty PC, Tonegawa S 1994 Altered peptidase and viral-specific T cell response in LMP-2 mutant mice. Immunity 1:533-541

Verma IM, Stevenson EM, Schwarz DV, Antwerp S, Miyamoto S 1995 Rel/NF- $\kappa$ B/I $\kappa$ B family: intimate tales of association and dissociation. Genes Dev 9:2723-2735

Vidal-Puig A, Faustman DL 1994 Tolerance to peripheral tissue is transient and maintained by tissue specific class I expression. Transplant Proc 26:3314-3316

Vives-Pi M, Armengol MP, Alcalde L, Costa M, Somoza N, Vargas F, Jaraquemada D, Pujol-Borrell R 1996 Expression of transporter associated with antigen processing-1 in the endocrine cells of human pancreatic islets: effect of cytokines and evidence of hyperexpression in IDDM. Diabetes 45:779-788

Wakatsuki Y, Neurath MF, Max EE, Strober W 1994 The B cell-specific transcription factor BSAP regulates B cell proliferation. J Exp Med 179:1099-1108

Wallach D, Varfolomeev EE, Malinin NL, Goltsev YV, Kovalenko AV, Boldin MP 1999 Tumor necrosis factor receptor and Fas signaling mechanisms. Annu Rev Immunol 17:331-367

Wang CY, Mayo MW, Baldwin AS 1996 TNF- and cancer therapy-induced apoptosis potentiation by inhibition of NF- $\kappa$ B. Science 274:784-787

Watanabe-Fukunaga R, Brannan CI, Copeland NG, Jenkins NA, Nagata S 1992 Lymphoproliferation disorder in mice explained by defects in Fas antigen that mediates apoptosis. Nature 356:314-317

Watson ML, Rao JK, Gilkeson GS, Ruiz P, Eicher EM, Pisetsky DS, Matsuzawa A, Rochelle JM, Seldin MF 1992 Genetic analysis of MRL-lpr mice: relationship of the Fas apoptosis gene to disease manifestations and renal disease-modifying loci. J Exp Med 176:1645-1656

Weih F, Carrasco D, Durham SK, Barton DS, Rizzo CA, Ryseck RP, Lira SA, Bravo R 1995 Multiorgan inflammation and hematopoietic abnormalities in mice with a targeted disruption of RelB, a member of the NF- $\kappa$ B/Rel family. Cell 80:331-340

Weringer EJ, Like AA 1988 Identification of $\mathrm{T}$ cell subsets and class I and class II antigen expression in islet grafts and pancreatic islets of diabetic BioBreeding/Worcester rats. Am J Pathol 132:292-303

Wong HK, Kammer GM, Dennis G, Tsokos GC 1999 Abnormal NF- $\kappa$ B activity in T lymphocytes from patients with systemic lupus erythematosus is associated with decreased p65-RelA protein expression. J Immunol 163:1682-1689

Wu J, Wilson J, He J, Xiang L, Schur PH, Mountz JD 1996a Fas ligand mutation in a patient with systemic lupus erythematosus and lymphoproliferative disease. J Clin Invest 98:1107-1113 
Wu M, Lee H, Bellas RE, Schauer SL, Arsura M, Katz D, FitzGerald MJ, Rothstein TL, Sherr DH, Sonenshein GE 1996b Inhibition of NF- $\kappa$ B/Rel induces apoptosis of murine B cells. EMBO J 15:4682-4690

Yan G, Fu Y, Faustman DL 1997 Reduced expression of Tap1 and Lmp2 antigen processing genes in the nonobese diabetic (NOD) mouse due to a mutation in their shared bidirectional promoter. J Immunol 159:3068-3080

Yang XD, Tisch R, Singer SM, Cao ZA, Liblau RS, Schreiber RD, McDevitt HO 1994 Effect of tumor necrosis factor $\alpha$ on insulin-dependent diabetes mellitus in NOD mice. I. The early development of autoimmunity and the diabetogenic process. J Exp Med 180:995-1004 